\title{
Raised intraocular pressure postmaxillectomy and orbital floor reconstruction surgery
}

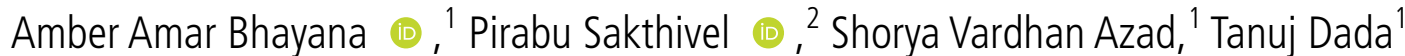

${ }^{1}$ Ophthalmology, Dr Rajendra Prasad Centre for Ophthalmic Sciences, All India Institute of Medical Sciences, New Delhi, India

${ }^{2}$ ENT \& Head and Neck Surgery, All India Institute of Medical Sciences, New Delhi, India

\section{Correspondence to}

Dr Shorya Vardhan Azad; shoryaazad@hotmail.com

Accepted 30 September 2020

\section{DESCRIPTION}

A 25 -year-old man, case of malignant peripheral nerve sheath tumour with orbital invasion (figure 1), underwent right-sided extended total maxillectomy including removal of orbital floor, periorbital and part of inferior and lateral rectus muscles along with orbital floor reconstruction using temporaliscoronoid tendon transfer (figure 2A). A routine bedside ophthalmic evaluation was sought postoperatively for chemosis and proptosis with limited ocular movements in the right eye (RE). Vision was atleast 6/60. On fundus examination (bedside indirect ophthalmoscopy) of RE, significant disc pulsations (figure $2 \mathrm{~B}$ and video 1 ) were noted suggesting raised intraocular pressure (IOP) to intracranial pressure ratio. ${ }^{12}$ Left eye (LE) was normal. The patient was immediately called to ophthalmology out-patient department for detailed workup. IOP on applanation tonometry was 56 and $16 \mathrm{~mm} \mathrm{Hg}$ in RE and LE, respectively. Apart from conjunctival congestion and chemosis, the slit lamp examination for the RE was normal. Gonioscopy could not be performed as patient was uncooperative. Anterior segment examination was unremarkable in LE. Patient was started on maximum antiglaucoma medications, however, IOP remained uncontrolled. CT scan imaging ruled out any space-occupying lesion in the orbit-like haematoma causing orbital compartment syndrome. Diode laser cyclophotocoagulation (DLCP) was done subsequently for IOP control. Two weeks postcyclophotocoagulation, IOP reduced to $26 \mathrm{~mm} \mathrm{Hg}$ with disappearance of disc pulsations. In light of the course of events, diagnosis of post maxillectomy glaucoma was made. IOP 2 months postmaxillectomy and DLCP was found to be $18 \mathrm{~mm} \mathrm{Hg}$ on topical brimonidine and timolol with visual acuity of 20/60. Proptosis had subsided by the time (figure 2C,D).

Compartment syndrome due to postsurgery, soft tissue swelling was our first differential diagnosis. The soft tissue swelling subsided with time, so did the compartment syndrome and the IOP pressure reduced. But had it been the only cause, the final pressure after resolution of soft tissue swelling should have been perfectly matched within normal limits. Even after suppressing aqueous production with DLCP, our patient required two topical antiglaucoma medications to maintain IOP of $18 \mathrm{~mm}$ $\mathrm{Hg}$ suggesting compartment syndrome was not the only cause for glaucoma. The other contributing factor could be extensive damage to periorbital tissue, episcleral veins and bulbar conjunctiva during tumour removal, resulting in interference with aqueous drainage. Aqueous humour drains into

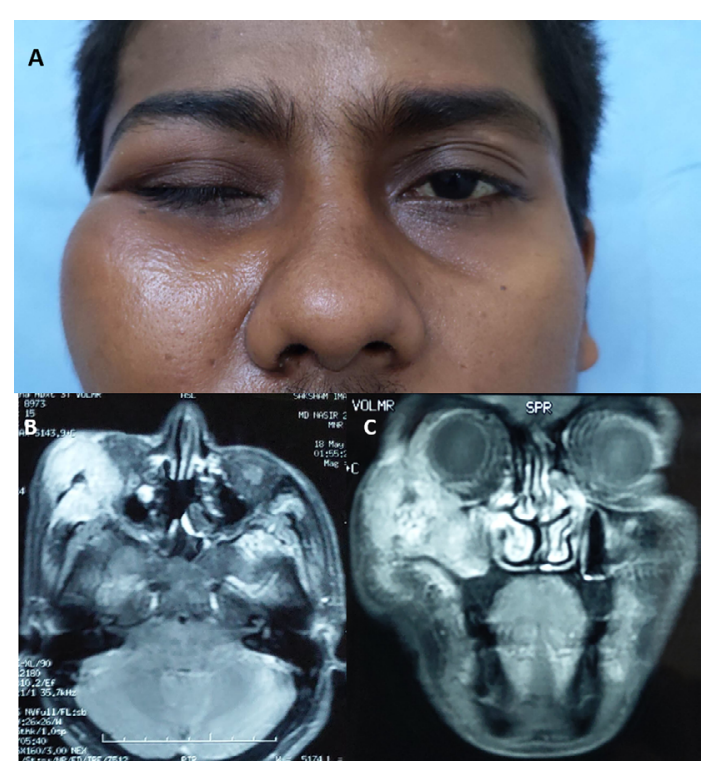

Figure 1 Clinical image depicting the tumour with orbital involvement (A); axial (B) and coronal (C) Contrast enhanced magnetic resonance imaging showing a heterogeneous enhancing lesion involving the entire right maxilla, extending into the orbit and infratemporal fossa.

Schlemm's canal via trabecular meshwork. From here, it proceeds to the aqueous vein via collector channels and then to the episcleral and conjunctival veins. ${ }^{3}$ IOP is the balance between aqueous production rates and the episcleral venous pressure. Elevated episcleral pressure is thus a cause of ocular hypertension. ${ }^{45}$ Significant damage to conjunctiva

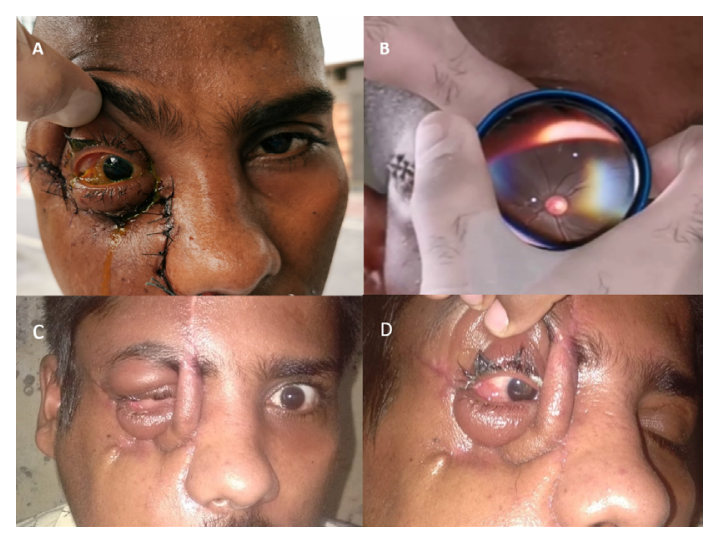

Figure 2 Postoperative clinical image depicting the congestion of cornea (A); (B) showing indirect ophthalmoscopic examination of optic disc; (C) and (D) showing 2 months postoperative picture with significant enophthalmos. 


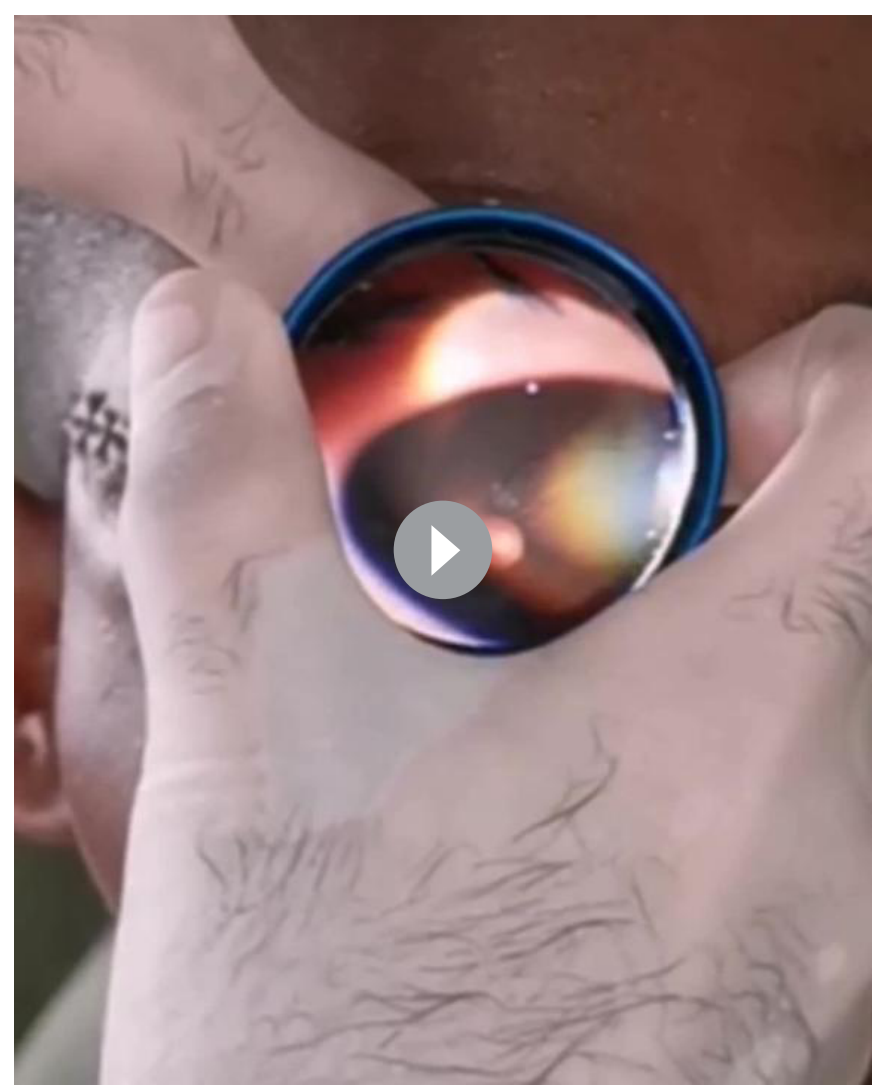

Video 1 Significant disc pulsations as seen on indirect ophthalmoscopy in the right eye.

and tenon's tissue might have affected conjunctival and episcleral drainage, leading to increase in IOP. ${ }^{6}$ Gross chemosis and conjunctival congestion could be the result of either two or additive effect of the above-mentioned two causes.

Our case highlights two essential points. First, that excessive damage to orbital soft tissue and conjunctiva in any surgery (orbital, sinuses, orbital apex etc) can secondarily lead to increase in IOP, causing ischaemic damage to optic nerve and visual decline in a previously asymptomatic eye. Second, optic disc pulsation using a direct or indirect ophthalmoscope noted on bedside evaluation may hint to ocular hypertension, warranting comprehensive ophthalmic assessment.

\section{Learning points}

- Excessive damage to orbital soft tissue and conjunctiva in any surgery (orbital, sinuses, orbital apex etc) can secondarily lead to increase in intraocular pressure, causing ischaemic damage to optic nerve and visual decline in a previously asymptomatic eye.

- Optic disc pulsation using a direct or indirect ophthalmoscope noted on bedside evaluation may hint to ocular hypertension, warranting comprehensive ophthalmic assessment.

Contributors $A A B$ : diagnosis and manuscript preparation. PS: surgery and editing of manuscript. SVA: manuscript editing and critical review. TD: management.

Funding The authors have not declared a specific grant for this research from any funding agency in the public, commercial or not-for-profit sectors.

Competing interests None declared.

Patient consent for publication Obtained

Provenance and peer review Not commissioned; externally peer reviewed.

\section{ORCID iDs}

Amber Amar Bhayana http://orcid.org/0000-0002-0770-601X

Pirabu Sakthivel http://orcid.org/0000-0002-6941-9892

\section{REFERENCES}

1 Jacks AS, Miller NR. Spontaneous retinal venous pulsation: aetiology and significance. J Neurol Neurosurg Psychiatry 2003;74:7-9.

2 Firsching R, Schütze M, Motschmann M, et al. Venous opthalmodynamometry: a noninvasive method for assessment of intracranial pressure. J Neurosurg 2000:93:33-6.

3 Bron AJ, Tripathi RC, Tripathi BJ, et al. Wolff's anatomy of the eye and orbit. 8th edn. London: Chapman \& Hall Medical, 1997: 292-8.

4 Ruiz-Ederra J, Verkman AS. Mouse model of sustained elevation in intraocular pressure produced by episcleral vein occlusion. Exp Eye Res 2006;82:879-84.

5 Shareef SR, Garcia-Valenzuela E, Salierno A, et al. Chronic ocular hypertension following episcleral venous occlusion in rats. Exp Eye Res 1995;61:379-82.

6 Lee YR, Na JH, Kim JY, et al. Increased intraocular pressure after extensive conjunctival removal: a case report. Korean J Ophthalmol 2013;27:141-4.

Copyright 2020 BMJ Publishing Group. All rights reserved. For permission to reuse any of this content visit

https://www.bmj.com/company/products-services/rights-and-licensing/permissions/

BMJ Case Report Fellows may re-use this article for personal use and teaching without any further permission.

Become a Fellow of BMJ Case Reports today and you can:

- Submit as many cases as you like

- Enjoy fast sympathetic peer review and rapid publication of accepted articles

- Access all the published articles

- Re-use any of the published material for personal use and teaching without further permission

Customer Service

If you have any further queries about your subscription, please contact our customer services team on +44 (0) 2071111105 or via email at support@bmj.com.

Visit casereports.bmj.com for more articles like this and to become a Fellow 